\title{
Chemical and morphological diversity among wild populations of Hypericum aviculariifolium Jaub. et Spach subsp. depilatum (Freyn et Bornm.) N. Robson var. depilatum
}

\author{
Cuneyt Cirak ${ }^{1 \star}$, Aysel Özcan ${ }^{2}$, Emine Yurteri² ${ }^{2}$ Dursun Kurt ${ }^{1}$, Fatih Seyis ${ }^{2}$ \\ ${ }^{1}$ Ondokuz Mayis University, Vocational High School of Bafra, Samsun, Turkey \\ ${ }^{2}$ Recep Tayyip Erdoğan University, Faculty of Agriculture and Natural Sciences, Department of Field Crops, Rize, Turkey
}

\begin{abstract}
In this study, the chemical and morphological diversity among eleven wild populations of Hypericum aviculariifolium Jaub. et Spach subsp. depilatum (Freyn et Bornm.) N. Robson var. depilatum, an endemic Turkish species was studied. These populations were investigated for their contents of hypericin, pseudohypericin, hyperforin, the chlorogenic, neochlorogenic, caffeic and 2,4-dihydroxybenzoic acids, hyperoside, quercitrin, isoquercitrin, avicularin, 13,118 biapigenin, (+)-catechin and (-)-epicatechin as well as for their morphological traits, including density of leaf light and dark glands, leaf area, leaf length/width ratio and plant height. The top two-thirds of the plants representing thirty individuals was harvested at full flowering from eleven sites and analyzed for the content of bioactive compounds by high-performance liquid chromatography after being dried at room temperature. Morphological characterization of the wild populations was performed on twenty randomly selected individuals from each plant-growing locality. The content of the tested compounds, except for caffeic acid and avicularin, and some morphological traits, namely, the density of leaf translucent glands and black nodules and leaf area varied significantly with the investigated populations. It was observed that hypericin and pseudohypericin contents were connected positively with leaf black nodule density, but negatively with leaf area and the contents of hyperforin, quercitrin and 13,118-biapigenin were correlated positively with leaf translucent gland density. Data presented here could be useful in determining future targets for further wide-ranging studies on this endemic species as well as in identifying superior germplasm in terms of high chemical content.
\end{abstract}

Keywords: 13,118-biapigenin, chemical and morphological diversity, hyperforin, hypericin, Hypericum aviculariifolium, phenolic acids, pseudohypericin, quercitrin

\section{Introduction}

Hypericum genus (Hypericaceae) includes over 400 species with world-wide distribution and is one of the 100 largest genera including twenty two percentage of angiosperm variety (Carine and Christenhusz 2010). Among its members, only Hypericum perforatum L. has been investigated widely so far. This species, herbal preparations of which have been utilized largely as a medicine in the treatment of mild to moderate depression, especially over the last three decades (Ng et al. 2017), is considered officinal. Hypericum species are well-known medicinal plants and have been used for centuries as traditional healing agents owing to their large number of pharmacological activities. All these species have traditionally been used for sedative, wound healing, disinfectant and spasmolytic preparations in Turkish folk medicine with the local names of "sarıkantaron, askerotu, kılıç otu, kanlıot and kuzu kıran". Turkey is a centre of great extensity for the Hypericum genus and according to Güner et al. (2012) there are a total of 96 Hypericum taxa in the Turkish flora, of which 46 are endemic. Hypericum aviculariifolium Jaub. et Spach subsp. depilatum (Freyn et Bornm.) N. Robson var. depilatum [syn. Hypericum origanifolium var. depilatum (Freyn et Bornm.) N. Robson, sensu WFO 2019] is one of these endemic species (Davis 1988), growing wild in arid, stony and limy areas of Northern Turkey. The distri-

\footnotetext{
* Corresponding author e-mail: kalinor27@gmail.com
} 
bution range of this endemic species is very localized by its exogenously dormant seeds (Cirak et al. 2007a). Its shoots are up to $30 \mathrm{~cm}$ in length with yellow inflorescence and typical dark glands on all aerial parts (Fig. 1). Results of recent studies documenting the antibacterial (Gül et al. 2017) and antioxidant (Maltas et al. 2013) properties of $H$. aviculariifolium subsp. depilatum var. depilatum indicate that this endemic species can be a substitute for widely known $H$. perforatum L.

Naphthodianthrones, principally represented by hypericin and psudohypericin, the phloroglucinol derivatives adhyperforin and hyperforin, flavonoids such as rutin, hyperoside, quercetin and quercitrin, phenolic acids and essential oils with a wide range of bioactivities are considered to be the principal constituents of Hypericum plant taxa (Zhao et al. 2015). In the past, hypericins were indicated as the main chemicals responsible for the antidepressant activity of $\mathrm{Hy}$ pericum extracts; however, recent studies have proved that antidepressant activity is revealed synergistically by both hypericins and hyperforin (Nabavi et al. 2018). Hyperforin and its derivatives were also reported to induce antitumor, antiangiogenic and neuroprotective activities (Ma et al. 2018). Although hyperforin and hypericin have been indicated as providing essential support to the pharmacological activities of Hypericum-derived products, some other ingredients such as chlorogenic acid, quinic acid, hyperoside, rutin,

quercitrin, quercetin and amentoflavone were also reported significantly to promote the antidepressant (Tusevski et al. 2018), neuroprotective (Silva et al. 2008), antioxidant and antimicrobial (Zorzetto et al. 2015) activities.

A great number of Hypericum species have been subjected to studies, documenting their chemical content/composition from Turkish flora as well as other growing localities of the world such as Brazil, Iran, Jordan, Serbia, Italy, Portugal, Tunisia, Peru and Lithuania (Cirak et al. 2016, and references therein).

Results from the former works revealed significant differences attributed to concentrations of the ingredients among the various Hypericum species from several taxa (Cirak et al. 2016); diversified populations of the same species from various geographic regions (Nogueira et al. 2008), various phenological stages of the same species (Abreu et al. 2004) and between various shoots as well, regenerated from the same in vitro culture (Cellarova et al. 1994). However, the precise pattern of bioactive compound accumulations inside and among members of Hypericum genus is not fully understood. It is not explained to what extent the chemical content and composition bear upon specific genotypes within species. It is also not clarified how far plant geographic origin affects the spectrum of phytochemicals.

In our previous works, we reported $H$. aviculariifolium subsp. depilatum var. depilatum to include hypericins, hyper-

c
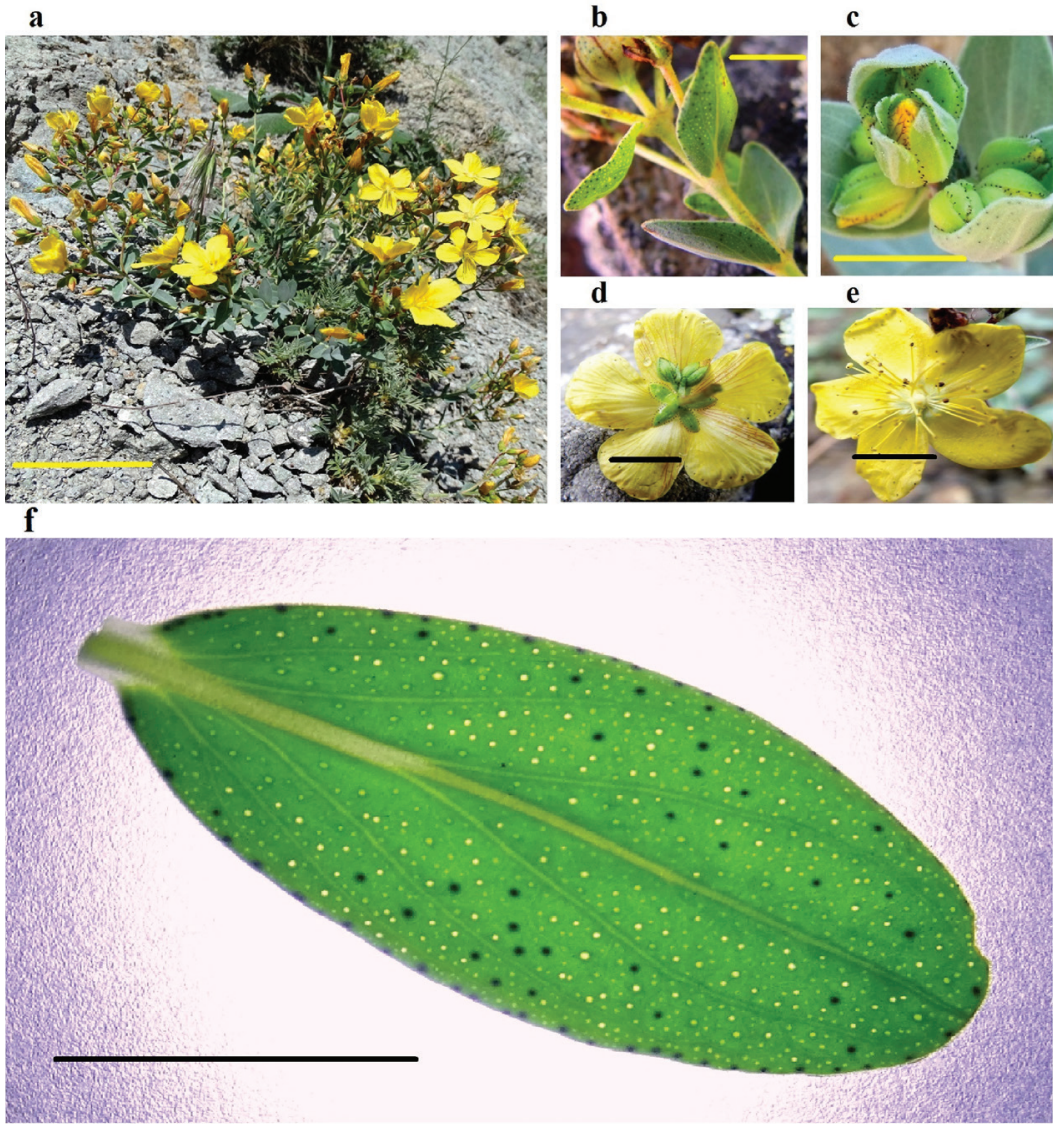

Fig. 1. Hypericum aviculariifolium subsp. depilatum var. depilatum plant flowering in its native habitat (a), and its aerial parts with typical dark glands, namely leaves and stems (b), floral buds (c) and flowers (d, e). Dark and translucent glands on leaf under dissecting microscope (f). Scale bars $=5 \mathrm{~cm}$ (a) and $1 \mathrm{~cm}(\mathrm{~b}-\mathrm{f})$. hyperoside, quercetine, chlorogenic acid, rutin, isoquercetine and quercitrine (Cirak et al. 2007b, 2013). However, population variability of the chemical compounds as well as of morphologic traits has not yet been studied with respect to the endemic species. Hence, in the present work, our intention has been to specify for the first time the regional variability in the content of hypericin, pseudohypericin, hyperforin, the chlorogenic, neochlorogenic, caffeic and 2,4-dihydroxybenzoic acids, hyperoside, quercitrin, isoquercitrin, avicularin, (+)-catechin, (-)-epicatechin and 13,118-biapigenin as well as five morphological traits including light and dark gland density on leaves, leaf area, leaf length/width ratio and plant height as well as the correlations between the chemical and morphological data among $H$. aviculariifolium subsp. depilatum var. depilatum populations from eleven localities in the Middle Black Sea geographic region of Northern Turkey. In addition, neochlorogenic, caffeic and 2,4-dihydroxybenzoic acids, 13,118-biapigenin, isoquercitrin, avicularin, (+)-catechin and (-)-epicatechin were not detected previously in this endemic species. Hereby, we also report the first occurrence of the corresponding compounds in $H$. aviculariifolium subsp. depilatum var. depilatum. 


\section{Materials and methods}

\section{Plant materials}

The plant materials were described in our previous studies (see Cirak et al. 2013, Cirak and Bertoli 2013). The species were identified by Dr. Samim Kayikci, Mustafa Kemal University, Faculty of Arts and Sciences, Department of Biology, Turkey. Voucher specimens were deposited in the herbarium of Ondokuz Mayis University Vocational High School of Bafra and the numbers of the voucher specimens are given in Tab. 1 .

\section{Experimental procedures}

The aerial parts of $H$. aviculariifolium subsp. depilatum var. depilatum plants exemplify 30 shoots were harvested at flowering stage from eleven localities in Middle Black Sea geographic region of Northern Turkey (Tab. 1). The top two thirds of the plants was reaped between 14:00 pm and 15:00 $\mathrm{pm}$. Conditions on the day of collection were clear and sunny at all sites and temperatures varied between 28 and $30^{\circ} \mathrm{C}$. The plant materials were dried at room temperature $(20 \pm$ $2{ }^{\circ} \mathrm{C}$ ), and subsequently analyzed for chemical in gredients by HPLC.

Morphological characterization of plants was made, as described previously in our previous study (Cirak et al. 2007b), on 20 randomly selected plants from each growing locality according to plant height, leaf dark and translucent gland density, leaf area, and leaf length/width ratio. Plant height was measured from the flowering crown of the primary stem to the base of the plant. Leaf area, leaf length/ width ratio and the number of dark and light spheroid nodules, were measured on 10 leaves of each selected plant from 11 different sites. The number of leaf dark and translucent glands was counted using a dissecting microscope (Fig. 1). For leaf area and leaf length/width ratio calculations, leaves were placed on aphotocopier, held flat and secure and copied onto an A3 sheet (at 1:1 ratio). Placom Digital Planimeter (Sokkisha Planimeter Inc., Model KP-90) was utilized to measure the actual leaf area of the copy. Leaf width $(\mathrm{cm})$ was measured from tip-to-tip at the widest part of the lamina and leaf length $(\mathrm{cm})$ was measured from lamina tip to the point of petiole intersection along the midrib.

\section{Preparation of plant extracts}

Air-dried plant material was mechanically ground using a laboratory mill to obtain a homogeneous drug powder. Samples of about $0.1 \mathrm{~g}$ (weighed with $0.0001 \mathrm{~g}$ precision) were extracted in $10 \mathrm{~mL}$ of $100 \%$ methanol by ultrasonication at $40^{\circ} \mathrm{C}$ for $60 \mathrm{~min}$ in an ultrasonic bath. The prepared extracts were filtered through a membrane filter with a pore size of $0.22 \mu \mathrm{m}$ (Carl Roth $\mathrm{GmbH}$, Karlsruhe, Germany) and kept in a refrigerator at $4{ }^{\circ} \mathrm{C}$ until analysis. The extracts for naphthodianthrones analyses were exposed to light under xenon lamp $\left(765 \mathrm{~W} / \mathrm{m}^{2}\right)$ for $8 \mathrm{~min}$ for the photoconversion of protohypericins into hypericins.

\section{HPLC Analyses and quantification}

Separation of the flavanoids and phenolic acids tested was carried out by using an RP-18 $(5 \mu \mathrm{m}, 250 \times 4.0 \mathrm{~mm})$ column in a Shimadzu LC-2030C-3D HPLC device equipped with a DAD detector. The binary gradient elution method was used for detection of corresponding compounds. The mobile phase A consisted of water acidified with $0.3 \%$ phosphoric acid as eluent $A$ and acetonitrile containing 0.3\% phosphoric acid as eluent $\mathrm{B}$. The elution profile was used as following: $0-10 \mathrm{~min} 10 \% \mathrm{~B}, 10-30 \mathrm{~min} 25 \% \mathrm{~B}, 30-38 \mathrm{~min}$ $60 \% \mathrm{~B}, 38-4560 \% \mathrm{~B}$ and $45-45.01 \mathrm{~min} 1 \% \mathrm{~B}$. Flow rate was $0.6 \mathrm{~mL} \mathrm{~min}^{-1}$ at $25{ }^{\circ} \mathrm{C}$ column temperature. The extract injection volume was $10 \mu \mathrm{L}$. The calibration of components was obtained at $203-280-320-360 \mathrm{~nm}$ wavelengths using $5,10,20,50,100$ and 200 ppm standard solutions.

For hypericin, pseudohypericin and hyperforin, the same device, Shimadzu LC-2030C-3D HPLC equipped with a DAD detector, was used. Separation of these chemicals was carried out using an RP-18 (5 $\mu \mathrm{m}, 250 \times 4.0 \mathrm{~mm})$ column. The mobile phase of isocratic solution consisted of ethyl acetate, aqueous $0.1 \mathrm{M}$ sodium dihydrogen phosphate solution was adjusted to $\mathrm{pH} 2.0$ by using phosphoric acid and methanol (39:41:160 v/v). The flow rate was $1 \mathrm{~mL} \mathrm{~min}^{-1}$ at $40{ }^{\circ} \mathrm{C}$ column temperature. The volume of extract injected was 20 $\mu \mathrm{L}$. The calibration of components was obtained at wavelengths 207 and $589 \mathrm{~nm}$ using 1, 5, 10, 20, 50 and 100 ppm standard solutions. Analytical standards used for HPLC analysis and validation values of the method are shown in On-line Suppl. Tab. 1. The standards are also described in On-line Suppl. Tab. 2.

Tab. 1. Geographical data and annual climatic conditions of Hypericum aviculariifolium subsp. depilatum var. depilatum-growing localities from Northern Turkey. BMYO stands for "Bafra Meslek Yüksekokulu”, Vocational High School of Bafra, Turkey; Popul. - population; Latit - latitude; Long - longitude Elev - elevation, T - mean annual temperature; P - mean annual precipitation

\begin{tabular}{|c|c|c|c|c|c|c|c|c|}
\hline Popul. & $\begin{array}{c}\text { Collection } \\
\text { date }\end{array}$ & $\begin{array}{c}\text { Voucher } \\
\text { no. }\end{array}$ & Latit $(\mathrm{N})$ & Long (E) & Elev (m) & $\mathrm{T}\left({ }^{\circ} \mathrm{C}\right)$ & $\mathrm{P}(\mathrm{mm})$ & Habitat \\
\hline 1 & June 03, 2018 & BMYO \# 27/1 & $40^{\circ} 54^{\prime}$ & $35^{\circ} 25^{\prime}$ & 1053 & 08.78 & 765 & Rocky and open slopes \\
\hline 2 & June 03, 2018 & BMYO \# 27/2 & $40^{\circ} 54^{\prime}$ & $35^{\circ} 38^{\prime}$ & 1075 & 08.52 & 782 & Rocky and open slopes \\
\hline 3 & June 03,2018 & BMYO \# 27/3 & $40^{\circ} 55^{\prime}$ & $35^{\circ} 25^{\prime}$ & 1293 & 08.07 & 821 & Rocky and open slopes \\
\hline 4 & June 03,2018 & BMYO \# 27/4 & $40^{\circ} 55^{\prime}$ & $35^{\circ} 24^{\prime}$ & 1452 & 07.52 & 875 & Rocky and open slopes \\
\hline 5 & June 03, 2018 & BMYO \# 27/5 & $40^{\circ} 50^{\prime}$ & $35^{\circ} 09^{\prime}$ & 952 & 09.29 & 922 & Igneous slopes and rock ledges \\
\hline 6 & June 04,2018 & BMYO \# 27/6 & $40^{\circ} 50^{\prime}$ & $35^{\circ} 10^{\prime}$ & 882 & 11.53 & 937 & Pinus woodland \\
\hline 7 & June 04, 2018 & BMYO \# 27/7 & $40^{\circ} 49^{\prime}$ & $35^{\circ} 09^{\prime}$ & 989 & 10.64 & 932 & Arid pasturelands \\
\hline 8 & June 04,2018 & BMYO \# 27/8 & $40^{\circ} 45^{\prime}$ & $35^{\circ} 08^{\prime}$ & 1243 & 09.11 & 856 & Stony riverside \\
\hline 9 & June 04, 2018 & BMYO \# 27/9 & $40^{\circ} 45^{\prime}$ & $35^{\circ} 07^{\prime}$ & 1373 & 08.77 & 872 & Stony riverside \\
\hline 10 & June 04,2018 & BMYO \# 27/10 & $40^{\circ} 45^{\prime}$ & $35^{\circ} 08^{\prime}$ & 1262 & 08.92 & 727 & Stony riverside \\
\hline 11 & June 04,2018 & BMYO \# 27/11 & $41^{\circ} 25^{\prime}$ & $36^{\circ} 58^{\prime}$ & 441 & 12.64 & 982 & Igneous slopes and rock ledges \\
\hline
\end{tabular}


Tab. 2. Mean contents ( $\mathrm{mg} \mathrm{g}^{-1} \mathrm{DM}$ ) of different compounds: hypericin (a), pseudohypericin (b), hyperforin (c), chlorogenic acid (d), neochlorogenic acid (e), caffeic acid (f), 2,4-dihydroxybenzoic acid (g), 13,118-biapigenin (h), hyperoside (i), isoquercitrin (j), quercitrin $(\mathrm{k})$, avicularin $(\mathrm{l}),(+)$-catechin $(\mathrm{m}),(-)$-epicatechin $(\mathrm{n})$ in Hypericum aviculariifolium subsp. depilatum var. depilatum populations (Popul.) located in Northern Turkey. Values are means of three replications and those, followed by different small letters in each column are significantly different $(\mathrm{P}<0.01)$ according to Duncan's Multiple Range test. $\mathrm{Se}=$ standard errors

\begin{tabular}{|c|c|c|c|c|c|c|c|c|c|c|c|c|c|c|}
\hline \multirow{2}{*}{ Popul. } & \multicolumn{14}{|c|}{ Compounds } \\
\hline & $\mathrm{a}$ & $\mathrm{b}$ & c & $\mathrm{d}$ & $\mathrm{e}$ & $\mathrm{f}$ & g & $\mathrm{h}$ & $\mathrm{i}$ & $\mathrm{j}$ & $\mathrm{k}$ & 1 & $\mathrm{~m}$ & $\mathrm{n}$ \\
\hline 1 & $0.14 \mathrm{~d}$ & $1.17 \mathrm{~d}$ & $0.25 \mathrm{c}$ & $12.13 \mathrm{~b}$ & $0.47 \mathrm{c}$ & 0.25 & $0.26 \mathrm{~b}$ & $1.30 \mathrm{~b}$ & $0.11 \mathrm{c}$ & $0.51 \mathrm{a}$ & $2.53 \mathrm{e}$ & 0.65 & $1.38 \mathrm{~b}$ & $1.05 \mathrm{~b}$ \\
\hline 2 & $0.28 \mathrm{c}$ & $1.93 \mathrm{c}$ & $0.21 \mathrm{c}$ & $9.91 \mathrm{c}$ & $0.69 \mathrm{~b}$ & 0.55 & $0.42 \mathrm{a}$ & $1.46 \mathrm{~b}$ & $0.24 \mathrm{~b}$ & $0.63 \mathrm{a}$ & $2.97 \mathrm{e}$ & 0.65 & $1.26 \mathrm{~b}$ & $0.79 \mathrm{c}$ \\
\hline 3 & $0.39 \mathrm{~b}$ & $2.10 \mathrm{c}$ & $0.07 \mathrm{de}$ & $7.64 \mathrm{c}$ & $0.45 \mathrm{c}$ & 0.26 & $0.09 \mathrm{c}$ & $1.29 \mathrm{~b}$ & $0.73 \mathrm{a}$ & $0.38 \mathrm{~b}$ & $3.65 \mathrm{~d}$ & 0.65 & $1.00 \mathrm{bc}$ & $0.69 c$ \\
\hline 4 & $0.31 \mathrm{c}$ & $3.53 \mathrm{~b}$ & $0.11 \mathrm{~d}$ & $2.11 \mathrm{e}$ & $0.19 \mathrm{e}$ & 0.32 & $0.14 \mathrm{c}$ & $1.09 \mathrm{~b}$ & $0.01 \mathrm{c}$ & $0.15 \mathrm{~d}$ & $2.16 \mathrm{e}$ & 0.64 & $0.47 \mathrm{c}$ & $0.21 \mathrm{~d}$ \\
\hline 5 & $0.27 \mathrm{c}$ & $1.67 \mathrm{~d}$ & $0.15 \mathrm{~d}$ & $3.45 \mathrm{de}$ & $0.27 \mathrm{~d}$ & 0.23 & $0.11 \mathrm{c}$ & $1.58 \mathrm{~b}$ & $0.01 \mathrm{c}$ & $0.16 \mathrm{~d}$ & $2.34 \mathrm{e}$ & 0.64 & $0.62 c$ & $0.11 \mathrm{~d}$ \\
\hline 6 & $0.30 \mathrm{c}$ & $2.16 \mathrm{c}$ & $0.03 \mathrm{e}$ & $4.47 \mathrm{~d}$ & $0.23 \mathrm{de}$ & 0.25 & $0.09 \mathrm{c}$ & $1.21 \mathrm{~b}$ & $0.36 \mathrm{~b}$ & $0.29 c$ & $5.93 \mathrm{c}$ & 0.65 & $0.68 c$ & $0.19 \mathrm{~d}$ \\
\hline 7 & $0.44 \mathrm{~b}$ & $2.64 \mathrm{c}$ & $0.01 \mathrm{e}$ & $4.56 \mathrm{~d}$ & $0.31 \mathrm{~d}$ & 0.27 & $0.09 \mathrm{c}$ & $0.98 \mathrm{c}$ & $0.01 \mathrm{c}$ & $0.24 \mathrm{c}$ & $5.00 \mathrm{c}$ & 0.64 & $0.69 c$ & $0.12 \mathrm{~d}$ \\
\hline 8 & $0.53 \mathrm{a}$ & $4.16 \mathrm{a}$ & $0.27 c$ & $11.81 \mathrm{~b}$ & $0.38 c$ & 0.24 & $0.58 \mathrm{a}$ & $1.59 \mathrm{~b}$ & $0.38 \mathrm{~b}$ & $0.42 \mathrm{~b}$ & $5.42 c$ & 0.66 & $1.65 \mathrm{~b}$ & $1.94 \mathrm{a}$ \\
\hline 9 & $0.55 \mathrm{a}$ & $4.85 \mathrm{a}$ & $0.34 \mathrm{c}$ & $3.31 \mathrm{~d}$ & $0.18 \mathrm{e}$ & 0.26 & $0.12 \mathrm{c}$ & $2.01 \mathrm{a}$ & $0.13 c$ & $0.22 c$ & $3.85 \mathrm{~d}$ & 0.66 & $0.68 c$ & $0.21 \mathrm{~d}$ \\
\hline 10 & $0.58 \mathrm{a}$ & $4.89 \mathrm{a}$ & $0.65 \mathrm{~b}$ & $8.86 \mathrm{c}$ & $0.42 \mathrm{c}$ & 0.28 & $0.29 \mathrm{~b}$ & $1.97 \mathrm{a}$ & $0.44 \mathrm{~b}$ & $0.41 \mathrm{~b}$ & $6.57 \mathrm{~b}$ & 0.66 & $1.10 \mathrm{~b}$ & $1.11 \mathrm{~b}$ \\
\hline 11 & $0.31 \mathrm{c}$ & $2.16 \mathrm{c}$ & $1.63 \mathrm{a}$ & $21.71 \mathrm{a}$ & $0.85 \mathrm{a}$ & 0.27 & $0.22 \mathrm{~b}$ & $2.09 \mathrm{a}$ & $0.29 \mathrm{~b}$ & $0.45 \mathrm{~b}$ & $7.10 \mathrm{a}$ & 0.66 & $2.42 \mathrm{a}$ & $1.82 \mathrm{a}$ \\
\hline $\mathrm{S}_{\mathrm{e}}$ & 0.042 & 0.393 & 0.140 & 1.720 & 0.063 & 0.027 & 0.048 & 0.179 & 0.068 & 0.046 & 0.534 & 0.002 & 0.173 & 0.202 \\
\hline
\end{tabular}

\section{Data Analysis}

Data of secondary metabolites contents and morphological characters of plant material were subjected to one-way analysis of variance (ANOVA) and significant differences among mean values were tested with the Duncan Multiple Range Test $(\mathrm{P}<0.01)$. Correlation analysis was performed to clarify the relationship between the chemical and morphological data, and principal component analysis (PCA) was carried out to elucidate the relationship of investigated populations regarding the chemical and morphological diversity they exhibited by using the statistical software package XLSTAT2010 Trial Version. PCA analysis is the twodimensional visualization of the position of investigated accessions relative to each other. The principal components represent the axes which are the orthogonal projections for the values representing the highest possible variances in the case of PC1 and PC2. The obtained data were used to create scatter plot diagrams (Backhaus et al. 1989). Therefore, a factor analysis was performed, whereby each variable was used to calculate relationships between variable and investigated factors. Based on the obtained data the cluster dendrogram was created.

\section{Results}

Results of the present study indicate that the contents of hypericin, pseudohypericin, hyperforin, the chlorogenic, neochlorogenic and 2,4-dihydroxybenzoic acids, hyperoside, quercitrin, isoquercitrin, (+)-catechin, (-)-epicatechin and 13,118 -biapigenin in plants differed greatly by populations $(P$ $<0.01)$ whereas caffeic acid and avicularin were accumulated at similar levels in all growing localities. Plants from population-11 supplied the highest accumulation level of hyperforin, chlorogenic acid, neochlorogenic acid, 13,118-biapigenin, (+)-catechin and (-)-epicatechin $(1.63,21.71,0.85,2.09,2.42$ and $1.82 \mathrm{mg} \mathrm{g}^{-1} \mathrm{DM}$, respectively) whereas hypericin and pseudohypericin were yielded in the highest level by plants of population-10 (0.58 and $4.89 \mathrm{mg} \mathrm{g}^{-1} \mathrm{DM}$, respectively). 2,4-di- hydroxybenzoic acid and quercitrin were accumulated at significantly higher levels by plants of population-8 (0.58 and $7.10 \mathrm{mg} \mathrm{g}^{-1} \mathrm{DM}$, respectively). The highest accumulation level of hyperoside and isoquercitrin was reached in plants of population 3 and population 2 ( 0.73 and $0.63 \mathrm{mg} \mathrm{g}^{-1} \mathrm{DM}$, respectively) (Tab. 2). The present results also indicate that $H$. aviculariifolium subsp. depilatum var. depilatum accumulates lower concentrations of hyperforin, hypericin, psedohypericin, neochlorogenic acid, hyperoside, isoquercitrin, (+)-catechin and (-)-epicatechin, comparable concentrations of avicularin and 13,118-biapigenin and higher concentrations of chlorogenic acid, caffeic acid, 2,4-dihydroxybenzoic acid and quercitrin when compared to $H$. perforatum, a well known commercial source of the compounds examined (Tab. 3).

Significant variations $(\mathrm{P}<0.01)$ were also observed in mean values of leaf dark and translucent gland density and leaf area among the investigated populations; however, leaf length/width ratio and plant height did not vary with plant growing localities (Tab. 4). Results of correlation analysis indicated an evident connection between leaf dark gland density/leaf area and hypericin/pseudohypericin contents of plants and leaf translucent gland density and hyperforin, quercitrin and 13,118-biapigenin contents of plants. No significant correlation was determined among the rest of the morphological traits and secondary metabolites tested (On-line Suppl. Tab. 3).

The number of translucent glands and black nodules on leaf and leaf area varied considerably with the investigated populations. Leaf dark gland density was significantly higher in plants of the populations 10, 9 and 8 whose hypericin and pseudoypericin contents were also found to be significantly higher. In a similar way, population 11, which accumulated the highest hyperforin, quercitrin and 13,118-biapigenin contents, was found to be superior to the others with respect to leaf translucent gland density. Positive and significant relationships were determined between leaf dark gland density and hypericin $\left(\mathrm{r}^{2}=0.86, \mathrm{P}<0.01\right) /$ pseudohypercin 
Tab. 3. Comparison of the chemical content $\left(\mathrm{mg} \mathrm{g}^{-1} \mathrm{DM}\right)$ in Hypericum aviculariifolium subsp. depilatum var. depilatum (in the present study) and Hypericum perforatum, globally known commercial species of Hypericum genus (compiled from various relevant sources).

\begin{tabular}{lccl}
\hline \multicolumn{1}{c}{ Compound } & $\begin{array}{c}\text { H. aviculariifolium } \\
\text { subsp. depilatum } \\
\text { var. depilatum }\end{array}$ & H. perforatum & \\
\hline Hyperforin & $0.21-1.63$ & $8.35-11.50$ & Greeson et al. 2001, Maggi et al. 2004, Couceiro et al. 2006 \\
Hypericin & $0.14-0.58$ & $0.01-2.77$ & Sirvent et al. 2002, Southwell and Bourke 2001, Bagdonaite et al. 2010 \\
Psedohypericin & $1.17-4.89$ & $0.05-6.75$ & Ayan and Cirak 2008, Bagdonaite et al. 2010, Büter and Büter 2002, \\
& & & Bagdonaite et al. 2012 \\
Chlorogenic acid & $2.11-21.71$ & $1.11-2.19$ & Maggi et al. 2004, Cirak et al. 2007b, c \\
Neochlorogenic acid & $0.42-0.85$ & $3.34-4.25$ & Jürgenliemk and Nahrstedt 2002 \\
Caffeic acid & $0.23-0.55$ & $<0.01$ & Patocka 2003, Nahrstedt and Butterweck 1997 \\
2,4-dihydroxybenzoic acid & $0.09-0.58$ & trace & Jürgenliemk and Nahrstedt 2002 \\
Hyperoside & $0.01-0.73$ & $2.07-7.69$ & Maggi et al. 2004, Bagdonaite et al. 2012 \\
Quercitrin & $2.16-7.10$ & $0.05-4.77$ & Martonfi and Repcak 1994, Radusiene et al. 2004 \\
Isoquercitrin & $0.22-0.63$ & $3.19-6.99$ & Jürgenliemk and Nahrstedt 2002 \\
Avicularin & $0.64-0.66$ & $0.32-0.96$ & Wu et al. 2002, Wei et al. 2009 \\
13,118-biapigenin & $1.21-2.09$ & $1.78-2.65$ & Jürgenliemk and Nahrstedt 2002, Nahrstedt and Butterweck 1997 \\
$(+)-$ catechin & $0.62-2.42$ & $1.41-8.70$ & Ploss et al. 2001, Kalogeropoulos et al. 2010 \\
$(-)-$-epicatechin & $0.11-1.94$ & $20.6-118.9$ & Ploss et al. 2001, Kalogeropoulos et al. 2010 \\
\hline
\end{tabular}

${ }^{*}$ The lowest and highest contents of the corresponding compounds, observed in the present study.

$\left(\mathrm{r}^{2}=0.92, \mathrm{P}<0.01\right)$ contents and leaf translucent gland density and hyperforin $\left(\mathrm{r}^{2}=0.75, \mathrm{P}<0.05\right)$, quercitrin $\left(\mathrm{r}^{2}=0.71, \mathrm{P}<\right.$ $0.05)$ and 13,118 -biapigenin $\left(r^{2}=0.77, P<0.05\right)$ contents. As for the leaf area, the highest and lowest values were detected in population-1 and population-10 (11.38 and $4.82 \mathrm{~cm}^{2}$, respectively) yielding the highest and lowest levels of hypericin and pseudohypericin accumulations. Likewise, the populations producing higher amounts of hyperforin, quercitrin and 13,118-biapigenin had lower values of leaf area. Leaf area was found to be negatively correlated with the hypericin $\left(\mathrm{r}^{2}=\right.$ $0.81, \mathrm{P}<0.01)$ and pseudohypericin $\left(\mathrm{r}^{2}=0.86, \mathrm{P}<0.01\right)$ contents of plant material.
A two-dimensional (2D) visualization of the relative position of the phytochemicals tested was created by using the values of the principal components (the bioactive compounds examined here) relative to the investigated populations. This was provided by utilizing the principal component analysis (PCA). A biplot was created to see the correlations between samples and the investigated traits. Results of biplot analysis revealed that the investigated populations could clearly be differentiated according to their chemical contents and morphological traits. Populations 3, 4, 5, 6, 7 and 9 were different in plant height and populations 1 and 2 were different with regards to caffeic acid content and leaf

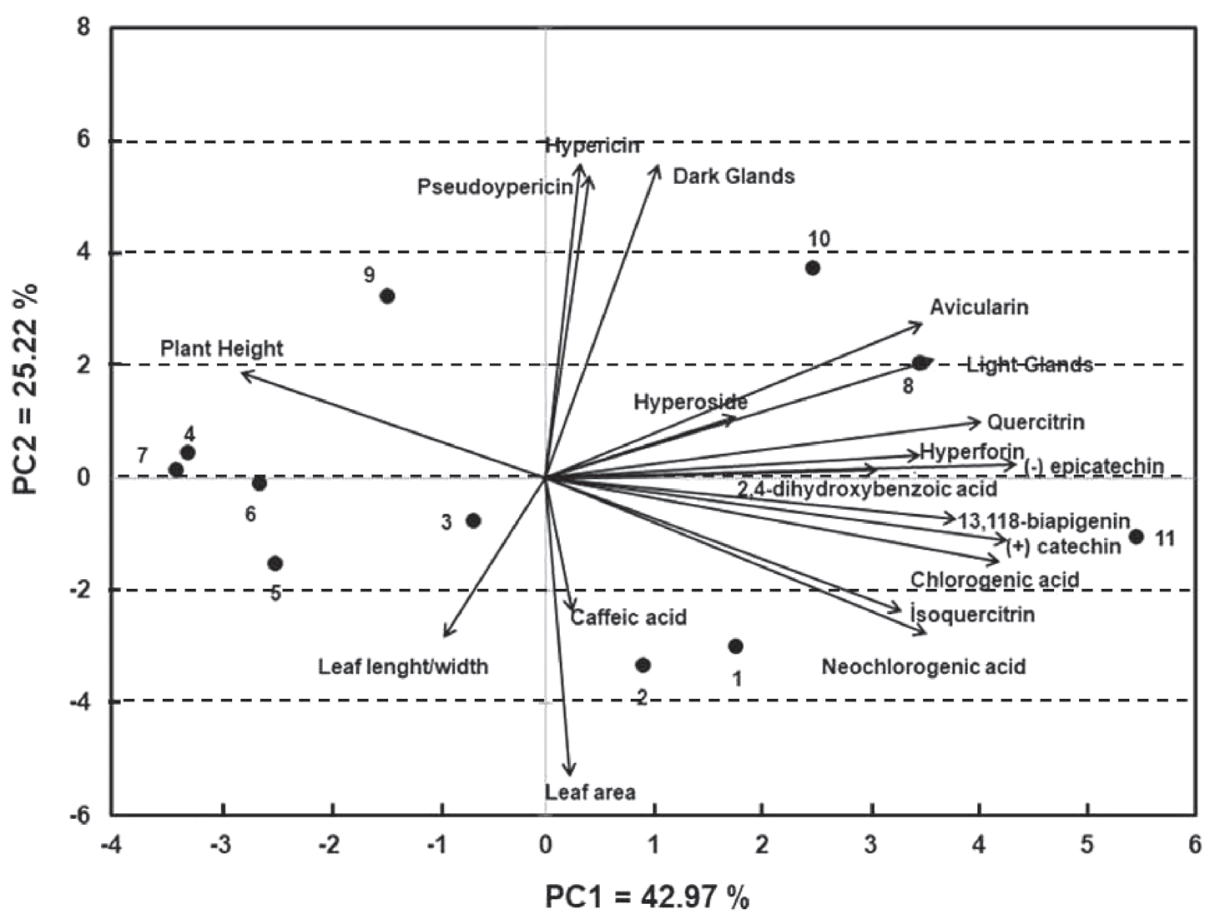

Fig. 2. Principal component analysis biplot showing populations (1-11) and vectors of the chemicals and morphological traits based on 20 samples for each population. 
Tab. 4. Mean values of the morphological characters evaluated in Hypericum aviculariifolium subsp. depilatum var. depilatum populations located in Northern Turkey. Values are means of three replications and those, followed by different small letters in each column are significantly different $(\mathrm{P}<0.01)$ according to Duncan's Multiple Range test. Se $=$ standard errors.

\begin{tabular}{cccccc}
\hline Population & Dark glands $\left(\right.$ per $\left.\mathrm{mm}^{2}\right)$ & Light glands $\left(\right.$ per mm $\left.{ }^{2}\right)$ & Leaf area $\left(\mathrm{cm}^{2}\right)$ & Leaf length/width & Plant height $(\mathrm{cm})$ \\
\hline 1 & $0.25 \mathrm{e}$ & $5.81 \mathrm{c}$ & $11.38 \mathrm{a}$ & 2.20 & 35 \\
2 & $0.30 \mathrm{e}$ & $5.01 \mathrm{c}$ & $10.39 \mathrm{~b}$ & 2.71 & 40 \\
3 & $0.32 \mathrm{e}$ & $4.20 \mathrm{~d}$ & $8.33 \mathrm{c}$ & 2.27 & 37 \\
4 & $0.48 \mathrm{c}$ & $4.83 \mathrm{~d}$ & $6.35 \mathrm{e}$ & 2.29 & 38 \\
5 & $0.30 \mathrm{~d}$ & $5.07 \mathrm{c}$ & $10.62 \mathrm{~b}$ & 2.11 & 36 \\
6 & $0.48 \mathrm{c}$ & $4.34 \mathrm{~d}$ & $7.99 \mathrm{c}$ & 2.36 & 42 \\
7 & $0.47 \mathrm{c}$ & $3.42 \mathrm{e}$ & $6.88 \mathrm{e}$ & 2.33 & 31 \\
8 & $0.64 \mathrm{~b}$ & $6.42 \mathrm{~b}$ & $7.59 \mathrm{~d}$ & 2.04 & 42 \\
9 & $0.66 \mathrm{~b}$ & $6.51 \mathrm{~b}$ & $5.67 \mathrm{f}$ & 2.36 & 39 \\
10 & $0.84 \mathrm{a}$ & $6.84 \mathrm{~b}$ & $4.82 \mathrm{~g}$ & 2.04 & 34 \\
11 & $0.49 \mathrm{c}$ & $7.30 \mathrm{a}$ & $7.69 \mathrm{~d}$ & 2.30 & 0.056 \\
$\mathrm{~S}_{\mathrm{e}}$ & 0.055 & 0.371 & 0.631 & & 0.878 \\
\hline
\end{tabular}

area. With the first two principal components, $68.19 \%$ of the present variation could be explained (Fig. 2).

Further, the investigated populations were differentiated into two main groups namely, group A including populations $1,2,3,4,5,6,7,9$ and group B consisting of populations $8,10,11$, with respect to their chemical contents and morphological traits on the dendogram, created by biplot analysis. As shown in Fig. 3, populations 1 and 2 and populations 4 and 7 from group A were found to be similar chemically and morphologically.

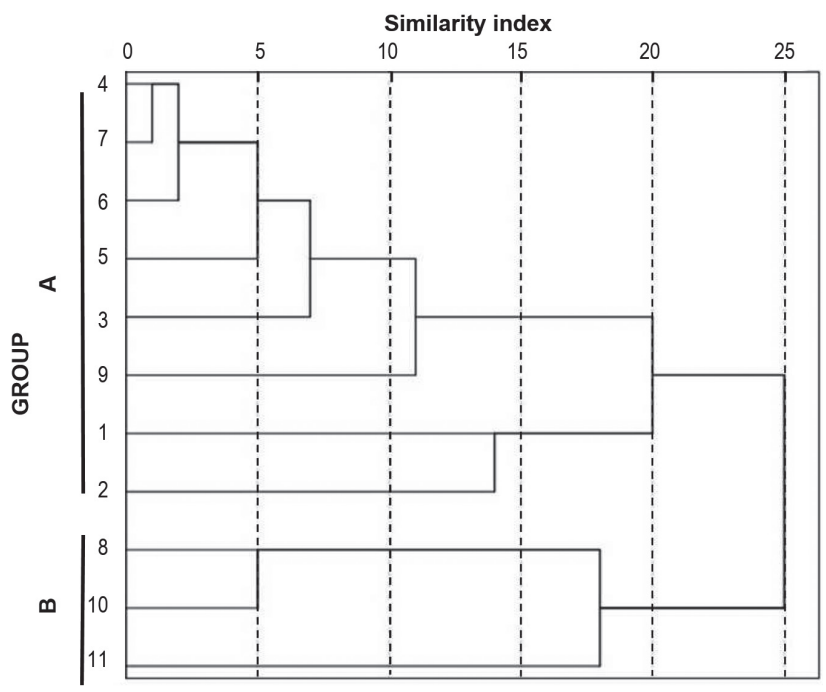

Fig. 3. Dendrogram showing the differentiated groups of Hypericum aviculariifolium subsp. depilatum var. depilatum populations (Group A represents populations 1, 2, 3, 4, 5, 6, 7 and 9; Group $B$ represents populations 8,10 and 11) regarding their chemical contents and morphological traits.

\section{Discussion}

Among the factors contributing to the variations in the phytochemical accumulation in the Hypericum genus, the geographic origin of plants is of considerable importance as the main environmental factors of a plant-growing habitat such as altitude, temperature, soil etc. influencing synthesis and accumulation of a given bioactive compound were diverse mainly according to the growing sites. The chemical heterogeneity of Hypericum plants from different origins is reported to influence the pharmacological activity of plant extracts significantly and to pose a great risk to the standardization of final Hypericum-derived products (Costa et al. 2016). Hence, there have been many investigations regarding population variability of bioactive compounds from $\mathrm{Hy}$ pericum species. In $H$. perforatum L., the most common and commercially recognized species of the genus, wild populations of Turkey (Cirak et al. 2007c), Canada, Australia, Armenia and Lithuania (Bagdonaite et al. 2010, and references therein) are shown to yield significantly different amounts of hyperforin, pseudohypericin and hyperforin. Essential oil composition is reported to differ significantly in accordance with the geographic origin of wild accessions of $H$. pulchrum L., H. humifusum L., H. perfoliatum L. and H. linarifolium Vahl. (Nogueira et al. 2008).

Considerable differences were determined in concentrations of hypericins, hyperforin and various phenolics such as rutin, hyperoside, amentoflavone and quercetin in the four wild accessions of $H$. triquetrifolium Turra from Turkey. In a similar way, eleven populations of $H$. orientale $\mathrm{L}$. and five wild populations of $H$. montbretii Spach and H. lydium Boiss. are reported to yield different quantities of hypericins, hyperforins, phenolic acids and several flavonoids such as hyperoside, quercetin, amentoflavone, rutin, avicularin isoquercitrin and quercitrin (Cirak et al. 2015, and references therein).

Results of previous studies indicated the geographic origin of plants as a distinct factor influencing the observed chemical variation among wild Hypericum populations. In a similar way, we observed significant differences in accumulation levels of 14 bioactive compounds among $H$. aviculariifolium subsp. depilatum var. depilatum from eleven geographic origins in the present work. Two populations of this endemic species are also reported to yield quantitatively and qualitatively different amounts of essential oil (Cirak and Bertoli 2013). The investigated populations varied with the main environmental factors creating different growing conditions as they were located in different places of Northern Turkey as shown in Table 1 . The wide variation observed in accumulation levels of the bioactive compounds tested among the populations could somewhat be attributed to adaptive 
strategies of wild plants to changing environmental factors. It is also possible to evaluate the observed chemodiversity among populations as a result of genetic distinctness, but data on the connection between the genetic and phytochemical structures in Hypericum spp. is scant and results are typically contradictory. For example, He and Wang (2013) reported only a partial correlation between chlorogenic acid, quercetin, rutin and hyperoside concentrations and genetic data of 12 wild $H$. perforatum populations from China. However, Tonk et al. (2011) detect significant connections between hypericin content and random-amplified polymorphic DNA (RAPD) data for 19 field-grown $H$. perforatum clones indicating the necessity for further chemical and molecular researches on the genus Hypericum to differentiate exactly the genetic and environmental effects on the monitored chemical variation among wild populations.

The comparison of eleven wild populations of $\mathrm{H}$. aviculariifolium subsp. depilatum var. depilatum revealed an intraspecific diversity in the distribution of light and dark glands corresponding with the accumulation of hypericins, hyperforin, quercitrin and 13,118-biapigenin in the present study. Hypericum plants are categorized generally by three types of secretory structures namely, translucent glands, black or dark nodules and secretory canals (Kimáková et al. 2018). Among Hypericum chemicals, hypericins are reported to accumulate most extensively in the black nodules of aerial parts (Kornfeld et al. 2007) and previous results have proved the localization of hypericin and pseudohypericin in the dark glands of plant aerial parts in all species producing hypericins (Kusari et al. 2015, Kuchariková et al. 2016a, b). Besides, the absence of dark glands in aerial parts is described as an accurate indication of the absence of hypericins in several species of Hypericum such as $H$. brasiliense Choisy, $H$. caprifoliatum Cham. et Schltdl., H. carinatum Griseb. (Ferraz et al. 2002), H. androsaemum L., H. kouytchense Levl., H. monogynum L., H. stellatum N. Robson, and H. canariense L. (Kuchariková et al. 2016a). In previous researches, a close relationship is observed between dark gland number of leaf and total hypericin content of plants in $\mathrm{H}$. perforatum (Southwell and Campbell, 1991) and H. lydium (Cirak 2006). In accordance with the previous results, we observed a positive and significant relationship with high $\mathrm{r}^{2}$ values between leaf dark gland density and the plant content of hypericin and pseudohypercin in the present work. We also detected that plant content of hypericins is negatively correlated with leaf area, as reported by Cirak et al. (2007c) for $H$. perforatum. It may be speculated that in the enlargement of leaf area concludes in a decrease of dark gland density and that the inverse connection between leaf area and the content of hypericins might be attributed to this decrease. As for hyperforin, Soelberg et al. (2007) report that concentrations of the bioactive compound in translucent glands of leaves surpassed that of original leaves by more than $100 \%$ in H. perforatum. Based on these results, the authors indicate translucent glands as the main site of hyperforin accumulation as confirmed latterly by Kusari et al. (2015). Hyperforin, besides, is reported to accumulate primarily in translucent glands of leaves in $H$. stellatum, $H$. annulatum Moris, $H$. androsaemum, $H$. kouytchense, $H$. monogynum, $H$. kalmianum L., H. balearicum L. and H. canariense (Kuchariková et al. 2016b). However, no attempt has been undertaken so far to investigate the correlation between number of translucent glands and content of hyperforin. We report here for the first time the significant and positive relationship between leaf translucent gland number and hyperforin accumulation levels which can be useful to explain sites of hyperforin synthesis and function of the bioactive compound within the genus Hypericum. As opposed to hypericins and hyperforin, it may not be feasible to ascertain a pattern of localization for flavonoids as data on the localization of them on the aerial parts are discrepant and vary with species. Hyperoside, isoquercitrin, quercetin and quercitrin were accumulated mainly in leaf dark glands of H. olympicum L., H. perforatum, and $H$. rumeliacum Boiss. and rutin was accumulated only in leaf black nodules of $H$. maculatum Crantz and $H$. erectum Thunb. However quercetin, the most prevalent flavonoid is reported to localize mainly in leaf translucent glands of $H$. rumeliacum (Kusari et al. 2015, Kuchariková et al. 2016a). Hyperoside and isoquercitrin, interestingly, are also reported to accumulate mainly in leaf translucent glands in $\mathrm{H}$. kalmianum (Kuchariková et al. 2016a). By contrast, hyperoside, isoquercitrin and quercitrin are accumulated primarily in both dark and translucent glands in H. humifusum leaves and quercetin and quercitin were accumulated principally in translucent glands and non-secretory structures in leaves of the species, namely, $H$. androsaemum, $H$. kouytchense, $H$. monogynum, H. stellatum (Kuchariková et al. 2016a). In the present study, we detected a positive and significant connection between leaf translucent gland density and the content of quercitrin and 13,118-biapigenin indicating translucent glands as the main site for the accumulation of corresponding compounds in $H$. aviculariifolium subsp. depilatum var. depilatum.

Principal component and cluster analyses are favored means for characterization of genotypes and their grouping on similarity. PCA is a beneficial statistical tool for the differentiation of plant materials, giving information on the variation in chemical content/composition of several species. A combination of the two statistical tools provides broad information of the traits making significant contributions to genetic diversity in crops. Biplot is another widely utilized procedure for graphical display of accession groups with the aim of searching for the relationships among agro-morphological characters in several cultivars (Malik et al. 2014). In the present study, we used the above mentioned statistical tools to evaluate the chemical and morphological data of eleven $H$. aviculariifolium subsp. depilatum var. depilatum populations from Turkish flora.

In conclusion, chemical and morphologic characterizations of wild plant populations seem to be first step to define superior germplasm and to provide improved chemical profiles. Results of the present study indicate substantial correlations between hypericin, pseudohypericin, hyperforin, quercitrin and 13,118-biapigenin contents and densi- 
ty of leaf dark and translucent glands and leaf area. Thus, these morphological characters could be utilized as selection criteria in identifying germplasm that is superior with regard to high contents of the corresponding compounds.

\section{References}

Abreu, I.N., Porto, A.L.M., Marsaioli, A.J. Mazzafera. P., 2004: Distrubution of bioactive substances from Hypericum brasiliense during plant growth. Plant Science 167, 949-954.

Ayan, A.K., Cirak, C., 2008: Hypericin and pseudohypericin contents in some Hypericum species growing in Turkey. Pharmaceutical Biology 46, 288-291.

Backhaus, K., Erichson, B., Plinke, W., Weiber, R., 1989: Multivariate analysis methods. Springer Verlag, Heidelberg.

Bagdonaite, E., Martonfi, P., Repcak, M., Labokas, J., 2010: Variation in the contents of pseudohypericin and hypericin in $\mathrm{Hy}$ pericum perforatum from Lithuania. Biochemical Systematics and Ecology 38, 634-640.

Bagdonaite, E., Martonfi, P., Repcak, M., Labokas, J., 2012: Variation in concentrations of major bioactive compounds in $\mathrm{Hy}$ pericum perforatum L. from Lithuania. Industrial Crops and Products 35, 302-308.

Büter, K.B., Büter, B., 2002: Ontogenetic variation regarding hypericin and hyperforin levels in four accessions of Hypericum perforatum L. Journal of Herbs Spices and Medicinal Plants 9, 95-100.

Carine, M.A., Christenhusz, M.J.M., 2010: About this volume, the monograph of Hypericum by Norman Robson. Phytotaxa $4,1-4$.

Cellarova, E., Daxnerova, Z., Kimáková, K., Haluskova, J., 1994: The variability of hypericin content in the regenerants of $\mathrm{Hy}$ pericum perforatum. Acta Biotechnologica 14, 267-274.

Cirak, C., 2006: Hypericin in Hypericum lydium Boiss. growing in Turkey. Biochemical Systematics and Ecology 34, 897-899.

Cirak, C., Bertoli, A., 2013: Aromatic profiling of wild and rare species growing in Turkey, Hypericum aviculariifolium Jaub. and Spach subsp. depilatum (Freyn and Bornm.: Robson var. depilatum and Hypericum pruinatum Boiss. and Bal. Natural Product Research 27, 100-107.

Cirak, C., Kevseroğlu, K., Ayan, A.K., 2007a: Breaking of seed dormancy in a Turkish endemic Hypericum species: Hypericum aviculariifolium subsp. depilatum var. depilatum by light and some pre-soaking treatments. Journal of Arid Environments 68, 159-164.

Cırak, C., Radusiene, J., Janulis, V., Ivanauskas, L., 2007b: Chemical constituents of some Hypericum species growing in Turkey. Journal of Plant Biology 50, 632-635.

Cirak, C., Radusiene, J., Sağlam, B., Janulis, V., 2007c: Variation of bioactive substances and morphological traits in Hypericum perforatum populations from Northern Turkey. Biochemical Systematics and Ecology 35, 403-409.

Cirak, C., Radusiene, J., Camas, N., Çalışkan, Ö., Odabas, M.S., 2013: Changes in the contents of main secondary metabolites in two Turkish Hypericum species during plant development. Pharmaceutical Biology 51, 391-399.

Cirak, C., Radusiene, J., Ivanauskas, L., Jakstas, V., Camas, N., 2015: Changes in the content of bioactive substances among Hypericum montbretii Spach (Hypericaceae: populations from Turkey. Brazilian Journal of Pharmacognosy 24, 20-24.

Cirak, C., Radusiene, J., Jakstas, V., Ivanauskas, L., Seyis, F., Yayla, F., 2016: Secondary metabolites of seven Hypericum species growing in Turkey. Pharmaceutical Biology 54, 2244-2253.

Costa, J., Campos, B., Amaral, J.S., Nunes, M.E., Oliveira, B.P.P., Isabella, M., 2016: HRM analysis targeting ITS1 and matK loci
Data presented here could also be useful in determining the forthcoming goals for further wide-ranging studies on this endemic species as well as enriching data of current literature on Hypericum chemistry.

as potential DNA mini-barcodes for the authentication of $\mathrm{Hy}$ pericum perforatum and Hypericum androsaemum in herbal infusions. Food Control 61, 105-114.

Couceiro, M.A., Afreen, F., Zobayed, S.M.A., Kozai, T., 2006: Variation in concentrations of major bioactive compounds of St. John's wort: Effects of harvesting time, temperature and germplasm. Plant Science 170, 128-134.

Davis, P.H., 1988: Flora of Turkey and the East Aegean Islands. Edinburgh University Press, Edinburgh.

Ferraz, A., Bordignon, S., Mans, D., Aline Schmitt, A., Ravazzolo, A.P., von Poser, G.L. 2002: Screening for the presence of hypericins in southern Brazilian species of Hypericum (Guttiferae). Pharmaceutical Biology 40, 294-297.

Greeson, JM., Sanford, B., Monti, D.A., 2001: St. John's wort (Hypericum perforatum L.), a review of the current pharmacological, toxicological and clinical literature. Psychopharmacology 153, 402-414.

Güner, A., Aslan, S., Ekim, T., Vural, M., Babaç, M.T., 2012: List of Turkish flora (Vascular plants). Publication of Nezahat Gökyiğit Botanical Garden and Flora Research Fondation, İstanbul. Retrieved December 23, 2019 from http://www.bizimbitkiler.org.tr/v2/hiyerarsi.php?c=Hypericum

Gül, L.B., Özdemir, N., Gül, O., Cirak, C., Çon, A.H., 2017: Bioactive properties and antimicrobial activity of some Hypericum species growing wild in Black Sea region of Turkey. In: Turker, S., Sahin, A.S., Ertekin, M., Soner, B.C., Unver, A., Dogu, S., Akyurek, H.E., Kozan, I. (eds.), Book of Abstract of the $1^{\text {st }}$ International Medicinal and Aromatic Plants Congress, 1336-1336. Konya, Turkey: Necmettin Erbakan University Publications.

He, M., Wang, Z., 2013: Genetic diversity of Hypericum perforatum collected from the Qinling Mountains of China. Biochemical Systematics and Ecology 50, 232-239.

Jürgenliemk, G., Nahrstedt, A., 2002: Phenolic Compounds from Hypericum perforatum. Planta Medica 68, 88-91.

Kalogeropoulos, N., Yannakopoulou, K., Gioxari, A., Chiou, A., Makris, D. P., 2010: Polyphenol characterization and encapsulation in $\beta$-cyclodextrin of a flavonoid-rich Hypericum perforatum (St. John's wort: extract, LWT). Food Science and Technology 43, 882-889.

Kimáková, K, Petijová L, Bruňáková K, Čellárová E., 2018. Relation between hypericin content and morphometric leaf parameters in Hypericum spp.: A case of cubic degree polynomial function. Plant Science 271, 94-99.

Kornfeld, A., Kaufman, P.B., Lu, C.R., Gibson, D.M., Bolling, S.F., Warber, S.L., Chang, S.C., Kirakosyan, A., 2007: The production of hypericins in two selected Hypericum perforatum shoot cultures is related to differences in black gland structure. Plant Physiology and Biochemistry 45, 24-32.

Kuchariková, A., Kusari, S., Sezgin, S., Spiteller, M., Cellárová, E., 2016a: Occurrence and distribution of phytochemicals in the leaves of 17 in vitro cultured Hypericum spp. adapted to outdoor conditions. Frontiers in Plant Science 7, 1616-15.

Kuchariková, A., Kimáková, K., Janfelt, C., Cellárová, E., 2016b: Interspecific variation in localization of hypericins and phloroglucinols in the genus Hypericum as revealed by desorption electrospray ionization mass spectrometry imaging. Physiologia Plantarum 157, 2-12. 
Kusari, S., Sezgin, S., Nigutova, K., Cellarova, E., Spiteller, M., 2015: Spatial chemo-profiling of hypericin and related phytochemicals in Hypericum species using MALDI-HRMS imaging. Analytical and Bioanalytical Chemistry 407, 4779-4791.

Ma, L., Pan, X., Zhou, F., Liu, K., Wang, L., 2018: Hyperforin protects against acute cerebral ischemic injury through inhibition of interleukin-17A-mediated microglial activation. Brain Research 1678, 254-261.

Maggi, F., Ferretti, G., Pocceschi, N., Menghini, L., Ricciutelli, M., 2004: Morphological, histochemical and phytochemical investigation of the genus Hypericum of the Central Italy. Fitoterapia 75, 702-711.

Malik, R., Sharma, H., Sharma, I., Kundu, S., Verma, A., Sheoran, S., Kumar, R., Chatrath, R., 2014: Genetic diversity of agromorphological characters in Indian wheat varieties using GT biplot. Australian Journal of Crop Science 8, 1266-1271.

Maltas, E., Uysal, A., Yildiztugay, E., Aladag, M.O., Yildiz, S., Kucukoduk, M., 2013: Investigation of antioxidant and antibacterial activities of some Hypericum species. Fresenius Environmental Bulletin 22, 862-869.

Martonfi, P., Repcak, M., 1994: Secondary metabolites during flower ontogenesis of Hypericum perforatum L. Zahradnictvi 21, 37-44.

Nabavi, S.M., Nabavi, S.F., Sureda, A., Caprioli, G., Lannarelli, R., Sokeng, A.J.T., Braidy, N., Khanjani, S., Moghaddam, A.H., Atanasov, A.G., Daglia, M., Maggi, F., 2018. The water extract of tutsan (Hypericum androsaemum L.) red berries exerts antidepressive-like effects and in vivo antioxidant activity in a mouse model of post-stroke depression. Biomedicine \& Pharmacotherapy 99, 290-298.

Nahrstedt, A., Butterweck, V., 1997: Biologically active and other chemical constituents of the herb of Hypericum perforatum L. Pharmacopsychiatry 30, 129-134.

Ng, Q.X., Venkatanarayanan, N., Ho, C.Y.X., 2017: Clinical use of Hypericum perforatum (St. John's wort: in depression: A meta-analysis. Journal of Affective Disorders 210, 211-221.

Nogueira, T.M.J., Marcelo-Curto, A., Figueiredo, C., Barroso, J.G., Pedro, L.G., Rubiolo, P., Bicchi, C., 2008: Chemotaxonomy of Hypericum genus from Portugal, geographical distribution and essential oils composition of Hypericum perfoliatum, Hypericum humifusum, Hypericum linarifolium and Hypericum pulchrum. Biochemical Systematics and Ecology 36, 40-50.

Patocka, J., 2003: The chemistry, pharmacology, and toxicology of the biologically active constituents of the herb Hypericum perforatum L. Journal of Applied Biomedicine 1, 61-70.

Ploss, O., Petereit, F., Nahrstedt, A., 2001: Procyanidins from the herb of Hypericum perforatum. Pharmazie 56, 509-511.
Radusiene, J., Bagdonaite, E., Kazlauskas, S., 2004: Morphological and chemical evaluation on Hypericum perforatum and $\mathrm{H}$. maculatum in Lithuania. Acta Horticulturae (ISHS) 629, 55-62.

Silva, B., Oliveira, P.J., Dias, A., Malva, J.O., 2008: Quercetin, kaempferol and biapigenin from Hypericum perforatum are neuroprotective against excitotoxic insults. Neurotoxicity Research 13, 265-279.

Sirvent, T., Walker, L., Vance, N., Donna, G., 2002: Variation in hypericins from wild populations of Hypericum perforatum L. in the Pasific Northwest of the U.S.A. Economic Botany 56, 41-49.

Soelberg, J., Jorgensen, L.B., Jager, A.K., 2007: Hyperforin accumulates in the traslucent glands of Hypericum perforatum. Annals of Botany 99, 1097-1100.

Southwell, I.A., Bourke, C.A., 2001: Seasonal variation in hypericin content of Hypericum perforatum L. (St. John's wort). Phytochemistry $56,437-441$.

Southwell, I.A., Campbell, M.H., 1991: Hypericin content variation in Hypericum perforatum L. in Australia. Phytochemistry $30,475-478$.

Tonk, F.A., Giachino, R.R.A., Sönmez, Ç., Yüce, S., Bayram, E., Telci, İ., Furan, M.A., 2011: Characterization of various $H y$ pericum perforatum clones by hypericin and RAPD analyses. International Journal of Agricultural Biology 13, 31-37.

Tusevski, O., Krstikj, M., Stanoeva, J.P., Stefova, M., Simic, S.G., 2018: Phenolic profile and biological activity of Hypericum perforatum L., Can roots be considered as a new source of natural compounds? South African Journal of Botany 117, 301-310.

Wei, Y., Xie, Q., Donga, W., Ito, Y., 2009: Separation of epigallocatechin and flavonoids from Hypericum perforatum L. byhigh-speed counter-current chromatography and preparativehigh-performance liquid chromatography. Journal of Chromatography A 1216, 4313-4318.

WFO 2019: Hypericum origanifolium var. depilatum (Freyn et Bornm.) N. Robson. Retreived December 27, 2019 from http://www.worldfloraonline.org/taxon/wfo-0000746600.

Wu, Y., Zhou, S.D., Li, P., 2002: Determination of flavonoids in Hypericum perforatum by HPLC analysis. Yao Xue Xue Bao 2000: 37, 280-282.

Zhao, J., Liu, W., Wang, J., 2015: Recent advances regarding constituents and bioactivities of plants from the genus Hypericum. Chemistry \& Biodiversity 12, 309-349.

Zorzetto, C., SAnchez-Mateo, C.C., Rabanal, R.M., Lupidi, G., Petrelli, D., Vitali, L.A., Bramucci, M., Quassinti, L., Caprioli, G., Papa, F., Ricciutelli, M., Sagratini, G., Vittori, S., Maggi, F., 2015: Phytochemical analysis and in vitro biological activity of three Hypericum species from the Canary Islands (Hypericum reflexum, Hypericum canariense and Hypericum grandifolium. Fitoterapia 100, 95-109. 